\title{
Имунологични, цитологични и алергологични проучвания върху ролята на фрунгите в патогенезата на хроничния риносинуит с носна полипоза
}

\author{
А. Куцаров ${ }^{1}$, И. Стоянов ${ }^{1}$, А. Тодорова \\ Р. Колева², Цветкова ${ }^{3}$, С. Гечева 4 \\ ${ }^{1}$ Клиника УНГ-болести, Медицински университет - Плевен \\ ЦЦитологична лаборатория кьм онкологичен центьр, МУ - Плевен \\ ${ }^{3}$ Медицински университет - Плевен, Клиника "Алергология" \\ ${ }^{4}$ Медицински университет - Плевен, Центьр по клинична имунология
}

\begin{abstract}
Chronic rhinosinusitis is a common disease. Some authors accept the leading role of Dematiaceous family fungi in its pathogenesis. Eosinophils are major actors in the immune reaction. The aim of the study is to determine the role of Dematiaceous family fungi and Aspergillus in pathogenesis of CRS with nasal polyposis. Material and methods: In the course of 4 months we examined 34 patients ( 20 females and 14 males) ( $40-65$ year old) with chronic rhinosinusitis (CRS) with nasal polyposis and 20 (12 females and 8 males) (40-65 year old)controls. Nasal secret was taken from all patients and controls for cytological exam. Skin prick test and sIgG to fungal allergens (Aspergillus, Alternaria, Fusarium, Rhizopus, Penicillium и Mucor) was performed with all patients and healthy controls.

Results: Cytologic examination of nasal smear showed: presence of fungal elements(hyphies) in 8 controls ( $80 \%$ ) and lack of eosinophils in all control subjects, while 24 patients had fungal elements $(70,58 \%)$ and eosinophils in $27(79,4 \%)$ of them. Skin prick tests were positive to one or several fungal types in 4 $(11,8 \%)$ of patients with poliposis and none of the control group. Examination of sera for specific $\operatorname{IgG}$ was positive in all groups. In the control group the titre of specific antibodies was $2,5-40 \mu \mathrm{g} / \mathrm{ml}$ while in the patients group the titre was significantly higher $(>40$ $\mu \mathrm{g} / \mathrm{ml})$ - in $28(82,4 \%)$ patients respectively.

Discussion: The aim of this study is to determine the role of fungi in pathogenesis of CRS with poliposis.
\end{abstract}

Key words: fungi, saprophit, chronic rhinosinusitis, fungal sinusitis, eosinophilic fungal rhinosinusitis

\section{Резюме}

Хроничният риносинуит е често срещано заболяване. Някои автори смятат, че водеща роля в етиопатогенезата на заболявансто имат гъбите от Dematiaceous family. Имунологичната реакция, която се развива, с с водещо участие на созинофилни клетки.

Целта на настоящото проучване е да сс докаже ролята на някои родове гъби от Dematiaceous family и Aspergillus в патогенезата на хроничния риносинуит с носна полипоза.

\section{Въведение}

Хроничният риносинуит (ХРC) е една от най-честите хронични болести в света. Тя засяга приблизително $15 \%$ от възрастното населението в западните страни [1].

Възпалителният процес причинява значителни субективни симптоми, които нарушават качеството на живот [2]. Освен това ХРС води след себе си до значителни финансови разходи [3]. Когато се съчетава със заболявания на долните дихателни пътища, това още повече нарушава живота на пациента [4]. Според съвременната европейска и американска класификации хроничният риносинуит се разделя на ХРС без и с носна полипоза. Етиологията на ХРС с носна полипоза е широко дебатирана, а патофизиологичните аспекти остават спорни. Противоречиви доклади се съобщават за ролята на гъбите в патогенезата на ХРС $[5,6]$. Присъствието на гъбите е предпоставка, която ще се установява и в бъдеще съществува ли причинноследствена връзка между гъбите и ХРС. Според някои автори гъбите имат отношение в развитието и поддържането на възпалителния процес при почти всички болни с XPC [5]. Гъбният риносинуит (FRS) се отличава от бактериалния и другите типове синуити не само по етиология, но така също по демографско разпространение сред населението, клиничната картина, методите за диагностика и лечение, както и по прогноза. Според хипотезата за ХРC, предложена от Ponikau et all. през 1999 г. [5], колонизиращите назалния секрет гъби имат основна роля в патогенезата на CRS (фиг. 
Материали и методи: В продължение на 4 месеца изследвахме 34 (20 жени и 14 мъже на възраст 40-62 г.) пациенти с диагноза ХРС (хроничен риносинуит) с носна полипоза и 20 (12 жени и 8 мъже на възраст 40-65 г.) здрави контроли. На всички изследвани ее извърши цитологично изследвапе па носен секрет, кожно-алергични проби и изследване за наличие на специфични $\operatorname{IgG}$ към следните родове гъби: Aspergillus, Alternaria, Fusarium, Rhizopus, Penicillium и Mucor. Резултати: Цитологичното изследване на носния секрет установи следното: контролната група наличие на гъби елементи (хифи) при 16 контроли (80\%) и липса на еозинофили при всички контроли. В групата на болните цитологично се установи наличието на хифи при 24 (70,58\%) пациенти и еозинофили при 27 (79,4\%).

Направените кожно-алергични проби бяха положителни към сдин или няколко рода при $4(11,76 \%)$ от болните и при нито една от контролите. Изследването на специфични IgG показа наличие на положителни стойности при всички изследвани групи.

Контролната група показа титър на специфичните антитела от 2,5-40 $\mu \mathrm{g} / \mathrm{ml}$. Групата на болните демонстрира титър на специфични антитела абнормно завишен $(>40 \mu \mathrm{g} / \mathrm{ml})$ при всички болните с полипоза.

Изводи: От направените проучвания се доказа наличие на еозинофилно възпаление при болшинството от болните $(79,58 \%)$ и липса на такова при контролната група. Наличие на гъби в назалния муцин се установи в $80 \%$ от болните и контролите. Кожно-алергичните проби показаха атопия (наличие на специфични гъбни ИгЕ) към изследваните родове гъби в $11,8 \%$ от болните и в нито една от контролите. Чрез изследването на специфични фунгиални $\operatorname{IgG}$ и цитологията на носния секрет се установи наличие на фунги и определяне на рода, към който принадлежат в болшинството от изследваните групи (80\%), но титьрът на специфичните гъбни IgG беше значително завишен $(>40 \mu \mathrm{g} / \mathrm{ml})$ при $28(82,4 \%)$ на болните.

Ключови думи: гъби, сапрофити, хроничен риносинуит, фунгален синуит, еозинофилен гъбен риносинуит.
1). Използвайки чувствителна техника за събиране на муцина и култивиране, в 93 процента от 101 пациенти с XРС са демонстрирани положителни гъбни култури в носния муцин. Ограничавайки диагностичните критерии до присъствието на гъби, еозинофили, както и разпадни продукти от еозинофилната дегранулация, са предложени нови критерии (приложими при всички пациенти с XPC). Един от критериите за поставяне на диагноза AFS е носната полипоза.

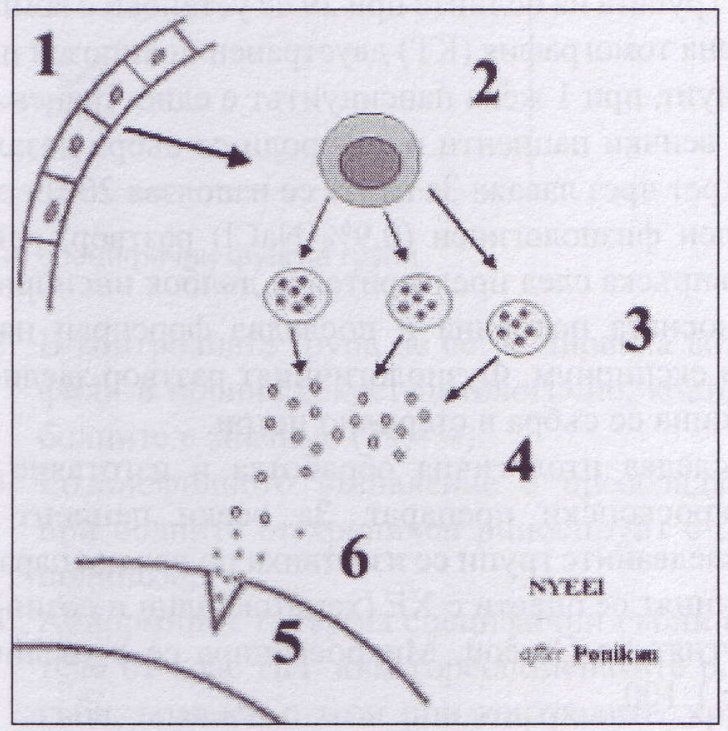

Фиг. 1. Схематично представяне на ролята на фунгите в патогенезата на XPC с еозинофилия по Ponikau J.

Гъбите са сапрофити, способни да образуват спори, и попадат върху носната лигавица чрез вдишвания през носа въздух. Ponikau (1999), Braun (2002) установяват в 100\% присъствието на фунги при здрави контроли. На основата на имунологично изследване при болни с алергична бронхопулмонална аспергилоза (АВРА) и AFS, Corey et all. [9] доказват, че се касае за тип I или по-често тип III имунна реакция. В алергичния гъбен синуит (AFS) антитела от клас $\mathrm{IgG}$, заедно с повишени нива на $\operatorname{IgE}$, могат да бъдат демонстрирани. Така те предлагат следното имунологично изследване: общи еозинофили, обши IgE, sIgE, sIgG. През 1998 г. сборна група автори доказали, че при AFS антигеньт(гъба), IgE и IgG медиирания отговор на повишена чувствителност е с последствие еозинофилна възпалителна реакция [10]. В други публикации Ponikau et all. [11] променят критериите, използвани за диагностиране на AFS от другите форми на ХРС. На болшинството от пациентите те не успели да установят повишена IgE-медиирана чувствителност към гъбни антигени. От тези резултати на фона на присъствието на еозинофили в алергичния муцин и липса на тип I имунен отговор в болшинството от случаите те предложили промяна в термина от AFS в еозинофилен гъбен риносинуит (EFRS). Аналогични резултати били получени и от Braun et all. [12]. 


\section{Материали и методи}

В продължение на 4 месеца изследвахме 34 (20 жени и 14 мъже на възраст 40-65 г.) пациенти с диагноза ХРС с носна полипоза и 20 (12 жени и 8 мъже на възраст 40-65 г.) здрави контроли. Всички пациенти и контроли не са приемали орални и/или назални кортикостероиди и антихистаминови препарати през последните 4 седмици, както и не са претърпели оперативна интервенция на синусите. От групата на болните при 29 се установи с компютърна томография (КТ) двустранен полипозен пансинуит, при 1 жена пансинуитът е едностранен.

На всички пациенти и контроли се събра назален секрет чрез лаваж. За целта се използва 20 мл стерилен физиологичен $(0,9 \% \mathrm{NaCl})$ разтвор, който се впръска след предварителен дълбок инспириум в носната половина и последва форсиран назален експириум. Фузиологичният разтвор заедно с муцина се събра в стерилно петри.

Последва цтологична обработка и изготвяне на микроскопски препарат. За всеки пациент от изследваните групи се изготвиха по два препарата. Единият се оцвети с XЕ (хематоксилин и еозин), а другият по Grocott. Микроскопира се с увеличение 1:100.

На всички пациенти и контроли се направиха кожно-алергични проби (КАП) към следните родове гъби: Aspergillus, Alternaria, Fusarium, Rhizopus, Penicillium и Mucor. От всички пациенти и контро- ли се взе венозна кръв, която след обработка се подложи на имунологично изследване по ELISA за наличие на специфични антитела от IgG клас срещу гореспоменатите родове гъби.

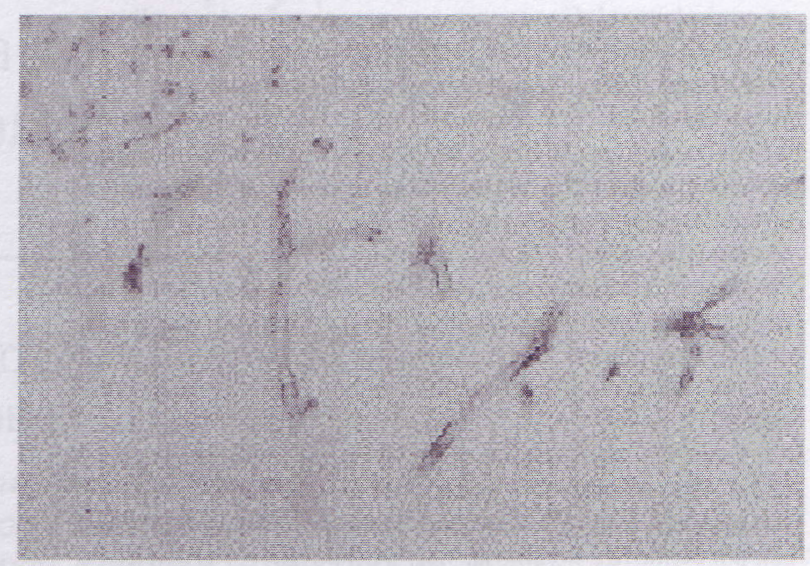

Фиг. 2. Цитологично фунги в назалния муцин, оцветен по Grocott

\section{Резултати}

При цитологичното изследване на носния секрет се установи следното: в контролната група наличие на гъби елементи (хифи) при 16 контроли $(80 \%)$ и липса на еозинофили при всички контроли (фиг. 2). При болните се установи наличие на хифи при 24 пациенти $(70,58 \%)$ и еозинофили при 27 (79,4\%). Графично резултатите са представени на фиг. 3.

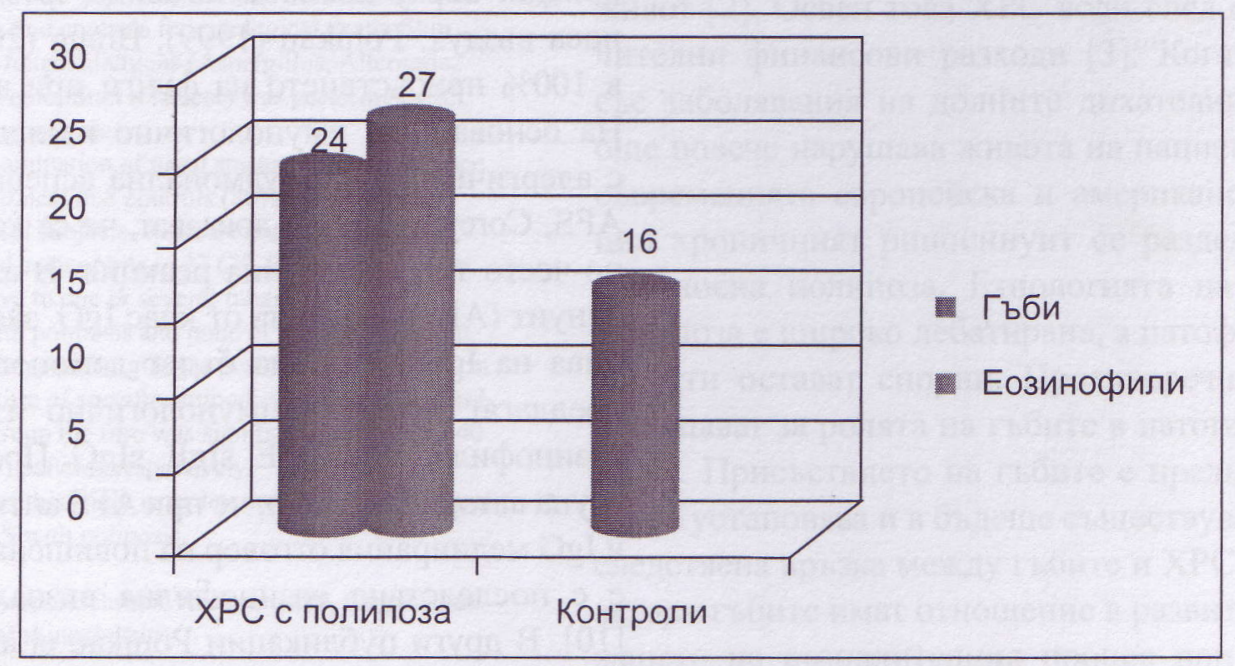

Фиг. 3. Резултати от цитологичното изследване на проучваните групи

От направените кожно-алергични проби се установиха положителни към един или няколко рода при $4(11,8 \%)$ от тези с полипоза. При контролната група не се установиха положителни кожноалергични проби. Изследването на специфични $\operatorname{IgG}$ показа наличие на положителни стойности при всички изследвани групи. Контролната група показа титър на специфичните антитела от 2,5$40 \mu \mathrm{g} / \mathrm{ml}$. При болните титьрьт на антителата беше патологично повишен (над $40 \mu \mathrm{g} / \mathrm{ml}$ ) спрямо контролната група при двадесет и осем $(82,4 \%)$ пациенти (фиг. 4). 


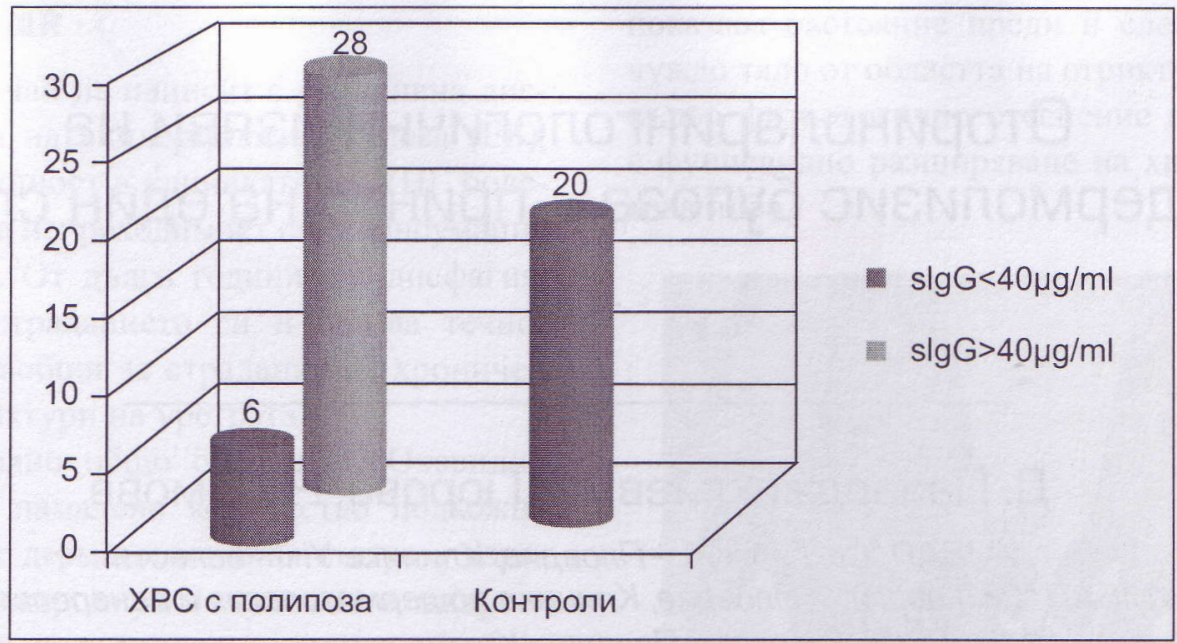

Фиг. 4. Резултати от изследването на специфични фунгиа групи

\section{Обосъждане}

Микробиологичната диагностика е бавен, икономически скъп тест, който не може да определи до колко фунгите участват в патологичния процес. Цитологичната диагностика доказва, без да идентифицира точния род, но е свързана с повишен риск от фалшиво отрицателни резултати. Тя е добър метод за откриване на еозинофили и други клетки на възпалението, което има място при отдиференциирането на неинвазивните от инвазивните форми. Имунологичната диагностика е сравнително бърза идентификация, както и за определяне на еозинофилия.

Необходими са по-задълбочени проучвания за установяване ролята на гъбите в патогенезата на хроничния риносинуит с еозинофилия полипоза,така и за тези без полипоза.

\section{Изводи}

От направените проучвания могат да се направят следните изводи:

1. Гъбите са нормални сапрофити в носната кухина на хората.

\section{Литература:}

1. Benson V, Marano MA. Current estimates from the National Health Interview Survey, 1995. Vital Health Stat 1998; 10:1-428.

2. Khalid AN, Quraishi SA, KennedyDW. Long-term quality of life measures after functional endoscopic sinus surgery. Am J Rhinol 2004; 18:131-136.

3. Ray NF, Baraniuk JN, Thamer M, et al. Healthcare expenditures for sinusitis in 1996: contributions of asthma, rhinitis, and other airway disorders. J Allergy Clin Immunol 1999; 103:408-414.

4. Ragab A, Clement P, Vincken W. Objective assessment of lower airway involvement in chronic rhinosinusitis. Am J Rhinol 2004; 18:15-21.

5. Ponikau JU, Sherris DA, Kern EB, et al. The diagnosis and incidence of allergic fungal sinusitis. Mayo Clin Proc 1999; 74:877--884.

6. Braun $\mathrm{H}$, Buzina W, Freudenschuss $\mathrm{K}$, et al. Eosinophilic fungal rhinosinusitis: a common disorder in Europe? Laryngoscope 2003; 113:264-269.
2. В контролната група не се установиха еозинофили в носния секрет цитологично, което при болните е значимо $(79,4 \%)$.

3. Еозинофилното възпаление е преобладаващо при болните от хроничен риносинуит с носна полипоза.

4. Абнормният титър на специфични гъбни антитела от клас ИгГ към гореспоменатите родове гъби, сравнен с този при контролите, красноречиво доказва ролята им в патогенезата на хроничния риносинуит с носна полипоза.

5. Ниският относителен дял на положителните кожно-алергични проби $(11,8 \%)$ към съответните родове се асоциира с наличие на специфични фунгиални ИгЕ и ИгЕ-медииран тип реакция.

6. От направените проучвания може да се заключи, че фунгите имат роля в патогенезата на хроничния риносинуит с полипоза основно по ИгГ (имунокомплексен) механизъм и по-рядко по комбиниран тип (ИгЕ-ИгГ медииран).

7. Geiser M, Leupin N, Maye I, et al. Interaction of fungal spores with the lungs: distribution and retention of inhaled puffball (Calvatia xcipuliformis) spores.J Allergy Clin Immunol 2000; 106:92-100.

8. Schubert MS. Medical treatment of allergic fungal sinusitis. Ann Allergy Asthma Immunol 2000; 85:90-101

9. Marple BF, Mabry RL. Comprehensive management of allergic fungal sinusitis. Am J Rhinol 1998; 12:263-268.

10. Quraishi HA, Ramadan HH. Endoscopic treatment of allergic fungal sinusitis. Otolaryngol Head Neck Surg 1997; 117:29-34.

11. Goldstein MF, Atkins PC, Cogen FC, Kornstein MJ, Levine RS, Zweiman B. Allergic Aspergillus sinusitis. J Allergy Clin Immunol $1985 ; 76: 515-524$

12. Kupferberg SB, Bent JP, Kuhn FA. Prognosis for allergic fungal sinusitis. Otolaryngol Head Neck Surg 1997; 117:35-41. 